\title{
PENGEMBANGAN PETERNAKAN BERSIH DI DESA NGUNUT KECAMATAN JUMANTONO KABUPATEN KARANGANYAR
}

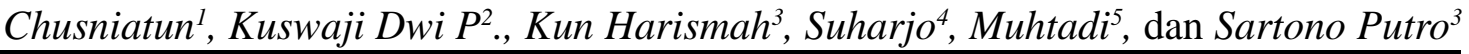 \\ ${ }^{1}$ Fakutas Agama Islam, \\ ${ }^{2}$ Fakultas Geografi \\ ${ }^{3}$ Fakultas Teknik \\ ${ }^{4}$ Fakultas Keguruan dan Ilmu Pendidikan \\ ${ }^{5}$ Fakultas Farmasi \\ Universitas Muhammadiyah Surakarta \\ Jl. A. Yani Tromol Pos I, Pabelan, Kartasura, Surakarta 57102 \\ Email : chusniatun_ums@yahoo.co.id
}

\begin{abstract}
In the Pemitra community service activities for development cleaner farming in Desa Ngunut Kecamatan Jumantono kabupaten Karanganyar, has been done for directing activities, training, and mentoring for farmers of cattle and chickens in Desa Ngunut, Jumantono, Karanganyar. In this Pemitra activities have been conducted briefings and training on producing of liquid and solid organic fertilizer, planting cassava and sengon by utilizing manure, the introduction of biogas technology applications on cattle ranchers. The results that have been obtained from this Pemitra community activities that partners have been able to understand and have the skills for managing livestock clean the biogas technology applications, the use of probiotics or fermentator in farm management, made of solid and liquid organic fertilizer, as well as the use of organic fertilizer for agricultural development cassava and sengon. The constraints and problems had been faced by the partners were 1) lack of farmer groups that have organizational unity in designing, managing, implementing and evaluating the work program. So that the unity and continuity in performing community service activities can not be done well, 2) Most of the participants were active in pemitra was the village officials and their family, so not much give a breadth of benefits to the general public.
\end{abstract}

Kata kunci: pengembangan peternakan bersih, desa Ngunut, Jumantono, Karanganyar

\section{PENDAHULUAN}

Desa Ngunut di Kecamatan Jumantono merupakan salah satu desa yang berada di Lereng Gunung Lawu sebelah barat, terletak pada $7^{\circ} 48^{\prime}-8^{\circ} 18^{\prime}$ 'Lintang Selatan dan $113^{\circ} 12^{\prime}-117^{\circ} 48^{\prime}$ Bujur Timur, dengan ketinggian daerah $\pm 316 \mathrm{~s} / \mathrm{d} 712 \mathrm{~m}$ dpal (di atas permukaan air laut). Luas wilayah Desa Ngunut tercatat 1.098 ha dengan kondisi topografi berbukit, terdiri dari 25 RT dan 8 RW dengan 9 Dukuh. Jumlah penduduk 4.116 jiwa (Laki-laki: 2.070 jiwa dan Perempuan: 2.046 jiwa), dengan jumlah KK Miskin sejumlah 200 KK. Status 
penduduk di Desa Ngunut sebagai PNS ada 68 orang, bekerja di sektor swasta ada 1.200 orang, dan sisanya sebagai petani dan buruh tani. Keadaan lahan pertanian berupa lahan tadah hujan dengan tamanan padi 1 kali panen dalam 1 tahun, tanaman pertanian lain adalah polowijo (jagung, ketela, dan kedelai). Sebagian lahan pertanian disewakan orang lain (WNI Keturunan China) untuk peternakan ayam, penyewa lahan jadi buruh pada sektor peternakan tersebut. Buruh tani yang lain melakukan aktivitas sambilan dengan memelihara sapi milik orang lain (sistem gadhon) dan sebagian kecil milik sendiri (12 ekor).

Perencanaan pembangunan Kabupaten Karanganyar tidak terlepas dari hierarki perencanaan pembangunan Nasional dan Daerah Provinsi Jawa Tengah. Dalam Undang-undang Nomor 25 Tahun 2004 tentang Sistem Perencanaan Pembangunan Nasional, Pemerintah Daerah baik Provinsi maupun Kabupaten/Kota, diamanatkan menyusun Rencana Pembangunan Jangka Panjang Daerah (RPJPD) yang merupakan dokumen perencanaan pembangunan untuk kurun waktu 20 (dua puluh) tahun. Dalam rangka pengintegrasian perencanaan pembangunan tersebut, penyusunan RPJPD Kabupaten Karanganyar Tahun 2005-2025 mengacu pada Rencana Pembangunan Jangka Panjang Nasional Tahun 2005 dan Rencana Pembangunan Jangka Panjang Daerah Provinsi Jawa Tengah Tahun 2005-2025.

RPJPD Kabupaten Karanganyar tahun 2005-2025, akan digunakan sebagai pedoman dalam penyusunan Rencana Pembangunan Jangka Menengah Daerah (RPJMD) Kabupaten Karanganyar pada setiap jangka waktu 5 (lima) tahunan. RPJPD Karanganyar merupakan perencanaan yang bersifat makro yang memuat visi, misi, arah, tantangan, dan prioritas pembangunan jangka panjang daerah. Dalam proses penyusunannya dilakukan secara partisipatif dengan melibatkan seluruh pemangku kepentingan pembangunan. (RPJP Kab. Karanganyar)

Pembangunan ekonomi di Kabupaten Karanganyar telah menunjukkan peningkatan yang signifikan, namun belum dapat meningkatkan kesejahteraan masyarakat dan lapangan kerja yang memadai. Maka dari itu tantangan pembangunan ekonomi dua puluh tahun ke depan adalah meningkatkan pertumbuhan ekonomi yang tinggi dan mampu meningkatkan pendapatan per kapita serta pemerataan, sehingga secara bertahap kesejahteraan masyarakat dapat mencapai tingkat kesejahteraan masyarakat minimal sesuai dengan Kabupaten/Kota se Propinsi Jawa Tengah.

Semakin intensifnya pasar bebas/ globalisasi menuntut peningkatan kualitas produk barang dan jasa secara kompetitif. Sehubungan dengan hal tersebut dalam rangka mendorong kemandirian ekonomi dan daya saing produk lokal di pasar regional maupun global, tantangan ke depan adalah meningkatkan kualitas dan produktivitas barang dan jasa.

Meningkatnya jumlah penduduk, alih fungsi lahan, eksploitasi lahan secara berlebihan dan terjadinya bencana alam dapat mengganggu ketahanan pangan. Tantangan ke depan adalah mengantisipasi, mengendalikan dan mengurangai secara bertahap permasalahan-permasalahan tersebut di atas serta berupaya meningkatkan produktivitas hasil-hasil pertanian secara berkelanjutan.

Dari survey lapangan didapatkan bahwa kelemahan dan kekurang-berdayaan petani sebagai produsen pangan organik tercermin dari kondisi berbagai aspek penting dalam usaha yang dilakukan petani, peternak, dan pengrajin kecil terutama aspek inovasi teknologi, aspek usaha, aspek permodalan, aspek diversifikasi produk, aspek pemasaran dan aspek sumber daya manusia, yang secara terperinci dapat diuraikan sebagai berikut. 


\section{Aspek inovasi teknologi}

Salah satu kenyataan di tingkat petani adalah bahwa sampai saat ini petani masih mengandalkan menggunakan pupuk anorganik dalam proses budidaya tanaman, belum memanfaatkan potensi lokal untuk dijadikan sumber pupuk organik. Sedangkan di tingkat peternak masih bersifat sebagai penerima teknologi belum sebagai pengguna teknologi peternakan, terutama teknologi: pakan, pembibitan, penanganan panen, pengolahan pasca panen, teknologi pengolahan kompos, pengobatan ternak, vaksinasi ternak. Peternak baik secara individu maupun sebagai kelompok, masih melaksanakan pendekatan pemeliharaan ternak secara tradisional atau cara pendekatan pemeliharaan ternak sebagaimana yang diperoleh secara turunmenurun serta ketergantungan pada kemurahan alam. Kalaupun ada sentuhan teknologi hanya dilakukan beberapa peternak di desa Ngunut dan itupun ala kadarnya.

\section{Aspek usaha}

Kondisi petani, peternak, dan pengrajin sebagian besar ditinjau dari aspek usaha memperlihatkan pengusahaan masih dalam skala kecil dan bersifat sambilan, sulit memperoleh informasi, kurang sarana dan lokasi tersebar luas, sehingga manajemen usahanya tidak efesien, biaya tinggi, tidak terpola dan kurang memiliki daya saing. Bidang usaha yang digeluti dikaitkan dengan sistem agribisnis umumnya bergerak pada kegiatan budidaya (on-farm) saja. Sementara kegiatan hulu dan hilir ditangani oleh pedagang desa. Petani dan peternak di Desa Ngunut mampu menjalin kerjasama atau kemitraan usaha dengan petani, peternak lain, koperasi atau dengan perusahaan.

\section{Aspek permodalan dan pembiayaan usaha peternakan}

Petani, peternak dan pengrajin sebagaimana cerminan dari usaha sambilan secara umum lemah dalam permodalan dan akses kepada lembaga keuangan juga kurang. Kelemahan permodalan ini tidak sematamata berpangkal pada tidak tersedianya modal di tingkat petani, peternak, dan pengrajin tetapi lebih karena faktor psikologis petani. peternak, dan pengrajin yang tidak menempatkan pembiayaan usaha peternakan sebagai prioritas.

Disisi lain sering kita lihat bahwa keberpihakan lembaga keuangan juga rendah terhadap usaha sambilan tersebut. Petani, peternak, dan pengrajin tidak memiliki agunan untuk perolehan kredit sebagaimana yang dipersyaratkan serta dinilai usahanya berisiko tinggi oleh lembaga keuangan. Bagi pihak lembaga keuangan mengurusi petani, peternak, dan pengrajin kecil yang tersebar meluas dan kemungkinan kredit kecilkecilan akan mengakibatkan kebutuhan tenaga pekerja, kerepotan dan biaya administrasi dan operasional lembaga keuangan menjadi tinggi.

\section{Aspek diversifikasi produk}

Hampir keseluruhan petani, peternak, dan pengrajin tidak memiliki kemampuan untuk melakukan diversifikasi produk dari usaha yang digelutinya, sehingga tidak memiliki nilai tambah. Petani, peternak, dan pengrajin cenderung menjualkan ternak ke pasar jika kebutuhan mendesak untuk perolehan uang tunai, sekalipun harga yang diajukan pembeli selalu lebih rendah dari harga sewajarnya.

Di sisi lain, limbah pertanian dan peternakan, baik padat maupun cair, belum dimanfaatkan secara optimal, padahal keduanya memiliki nilai ekonomi yang tinggi. Harga limbah cair, urine segar ternak sebesar Rp. 350,-/liter, setelah difermentasi menjadi Rp. 8.000,-/liter. Demikian juga limbah padat yang telah terfermentasi senilai Rp. 2000,-/kg. Pengelolaan limbah yang kurang baik akan menjadi masalah serius pada usaha peternakan. Sebaliknya bila limbah ini dikelola dengan baik dapat 
memberikan nilai tambah. Salah satu upaya untuk mengurangi limbah adalah mengintegrasikan usaha tersebut dengan beberapa usaha lainnya, seperti penggunaan suplemen pada pakan, usaha pembuatan kompos, budidaya ikan, budidaya padi sawah, sehingga menjadi suatu sistem yang saling sinergis. Upaya memadukan tanaman, ternak dan ikan di lahan pertanian memiliki manfaat ekologis dan ekonomis di Desa Ngunut, yang lahan pertaniannya didominasi lahan sawah tanah hujan. Laju pertumbuhan produktivitas usaha pertanian merupakan interaksi di antara berbagai faktor yang ada dalam sistem usahatani. Sebagai upaya bagi peningkatan sistem usahatani diperlukan teknologi alternatif untuk memperbaiki produktivitas lahan dan menjaga kelestarian lingkungan sekaligus meningkatkan pendapatan petani, antara lain melalui teknologi pertanian organik dan sistem usaha peternakan yang menerapkan konsep produksi bersih yang memanfaatkan kotoran ternak sapi untuk pembuatan biogas. Biogas diharapkan menjadi energy alternatif pedesaan yang ramah lingkungan, menuju kemandirian energy dan pangan.

\section{Aspek Pemasaran}

Petani, peternak dan pengrajin baik secara individu maupun secara kelompok belum mampu mempengaruhi pasar ternak, bahkan sangat tergantung terhadap peran pedagang pengumpul atau pedagang perantara. Petani, peternak, dan pengrajin tidak memiliki posisi tawar yang tinggi dan rantai pemasaran yang panjang serta fluktuasi harga yang tidak menentu. Ujung-ujungnya kesemua itu seringkali merugikan petani dan peternak sebagai produsen pangan dan ternak.

\section{Aspek Sumber Daya Manusia}

Petani dan peternak di Desa Ngunut umumnya menjalankan usahanya dengan segala keterbatasannya terutama usianya rata-rata telah lanjut dan tingkat pendidikan relatif rendah. Sedangkan angkatan muda yang rata-rata pendidikan lebih tinggi, kurang menaruh minat menekuni usaha pertanian organik dan pemeliharaan ternak.

Kondisi tersebut di atas sangatlah memprihatinkan karena kegiatan pembangunan di bidang pertanian dan peternakan yang dilaksanakan oleh pemerintah selama puluhan tahun dengan alokasi pembiayaan yang cukup besar masih belum membuahkan hasil optimal. Beranjak dari kenyataan ini, berarti kita masih perlu mengembangkan inovasi-inovasi praktis dan relevan dalam konsep pembangunan pertanian ke depan. Konsep tersebut haruslah mampu memberikan sentuhan perbaikan atas penyebab masih munculnya kelemahan-kelemahan yang tercermin dari berbagai aspek di atas.

Menarik untuk didukung adalah pendekatan PEMITRA dalam pengembangan usaha pertanian dan peternakan di Desa Ngunut ini adalah konsep pembangunan pertanian organik dan peternakan melalui pengembangan kawasan agribisnis berbasis pertanian organik, yang diartikan sebagai suatu proses pembangunan dalam suatu besaran/satuan wilayah tertentu dengan menerapkan pendekatan kelompok dengan komoditas unggulan yang dikelola secara agribisnis berkelanjutan yang berakses ke industri pertanian dan peternakan hulu sampai hilir.

Dengan konsep tersebut mengarahkan usaha pertanian organik dan ternak pada kondisi yang lebih berpeluang kepada peningkatan keuntungan dan daya saing, sebagai hasil dari kemudahan penyelenggaran berbagai kegiatan yang berpengaruh penting terhadap usaha ternak dan berada pada satu lokasi yang terjangkau, pemerintah berpeluang lebih mudah meningkatkan pelayanan teknis, penyediaan fasilitas secara efisien efektif, sehingga dapat menekan biaya transportasi, lebih menjamin terwujudnya keterkaitan agribisnis hulu-hilir, memudahkan pelaksanaan koordinasi dan pembinaan serta terwujudnya 
pola kemitraan peternak dengan pengusaha, peternak lebih cepat menjadi mandiri dengan skala usaha ekonomis.

Memperhatikan kondisi tersebut, maka tim pelaksana terdorong untuk mengembangkan PEMITRA untuk mengembangkan sistem produksi dan pengolahan hasil pertanian, peternakan dan perikanan dengan memanfaatkan potensi yang ada di sekitar desa tersebut dengan sistem yang sehat, praktis, produktif dan higienis.

Desa Ngunut, yang secara administratif termasuk di Kecamatan Jumantono, Kabupaten Karanganyar, Provinsi Jawa Tengah, termasuk desa yang terletak di lereng bawah Gunung Lawu sebelah barat, sebagian penduduknya bermata pencaharian sebagai buruh industri, petani, dan peternak.

Di bidang pertanian; permasalahan yang dihadapi adalah semakin meningkatnya biaya sarana produksi terutama pupuk anorganik, rendahnya tingkat pendapatan dan rendahnya perputaran modal, sehingga sektor pertanian belum memberi manfaat bagi perputaran ekonomi desa secara proporsional. Masalah-masalah utama petani kecil di Desa Ngunut ini terutama adalah pada aspek inovasi teknologi budidaya pertanian, aspek pengembangan usaha, aspek permodalan kelompok, aspek diversifikasi produk pertanian, aspek pemasaran produk pertanian usaha ikutannya dan aspek sumber daya manusia dalam menekuni usaha peternakan sebagai segmen ekonomi yang menjadi gantungan hidup mereka.

Di bidang peternakan; belum adanya peternak yang menerapkan konsep peternakan bersih, yang memanfaatkan kotoran ternak sapi untuk pembuatan biogas. Biogas diharapkan menjadi energy alternatif pedesaan yang ramah lingkungan, menuju kemandirian energy dan pangan. Penerapan peternakan bersih diharapkan dapat meningkatkan nilai ekonomi yang lebih tinggi. Harga limbah cair setelah difermentasi menjadi Rp. 8.000,-/liter, sedangkan limbah kotoran sapi (feses) yang telah terfermentasi senilai Rp. 600,-/kg. Pengelolaan limbah yang kurang baik akan menjadi masalah serius pada kesehatan lingkungan dan usaha peternakan. Sebaliknya bila limbah ini dikelola dengan baik dapat memberikan nilai tambah ekonomi, dan kebersihan lingkungan.

Pengelolaan peternakan yang tidak memperhatikan kebersihan lingkungan, akan menimbulkan permasalahan-permasalahan seperti rentan timbul konflik sosial, kesehatan lingkungan yang rendah, munculnya penyakit-penyakit endemik seperti disentri, kolera, dll. Oleh karenanya pengelolaan peternakan baik ayam maupun sapi sebaiknya dilakukan secara bersih dengan memperhatikan kualitas kesehatan lingkungan.

Konsep pengelolaan peternakan bersih dapat mengikuti prosedur produksi bersih (Cleaner Production) seperti yang dicetuskan oleh United Nation EnvironmentalProgram (UNEP) pada bulan Mei 1989. UNEP menyatakan bahwaCleaner Production merupakan suatu strategi pengelolaan lingkungan yang bersifat preventif, terpadu dan diterapkan secara kontinu pada proses produksi, produk dan jasa untuk meningkatkan eko-efisiensi sehingga mengurangi resiko terhadapkesehatan manusia dan lingkungan. Produksi bersih tidak hanya menyangkut proses produksi, tetapi juga menyangkut pengelolaan seluruh daur hidup produksi,yang dimulai dari pengadaan bahan baku dan pendukung, proses dan operasi,hasil produksi dan limbahnya sampai ke distribusi serta konsumsi.

Ada beberapa teknik pelaksanaan produksi bersih adalah (Afmar, 1999):

1. Pengurangan pada sumber merupakan pengurangan atau eliminasi limbah pada sumbernya, 
Seperti penggunaan probiotik untuk membantu mempercepat proses penguraian kotoran/limbah sehingga tidak menimbulkan bau yang umumnya mencemari lingkungan.

2. Daur ulang, daur ulang merupakan penggunaan kembali limbah dalam berbagai bentuk, diantaranya:

a. Dikembalikan lagi ke proses semula

b. Bahan baku pengganti untuk proses produksi lain

c. Dipisahkan untuk diambil kembali bagian yang bermanfaat

d. Diolah kembali sebagai produk samping.

Salah satu teknik di lapangan yang dapat diaplikasikan untuk mendukung peternakan bersih adalah aplikasi teknologi biogas dan pemanfaatan probiotik yang dicampurkan pada minuman atau makanan hewan peternakan, sehingga kotoran yang dihasilkan tidak lagi mencemari lingkungan dan mengundang kehadiran lalat.

Secara teoritis, biogas diproduksi oleh bakteri dari bahan organik di dalam kondisi tanpa oksigen (anaerobic process). Proses ini berlangsung selama pengolahan atau fermentasi. Gas yang dihasilkan sebagian besar terdiri atas $\mathrm{CH}_{4}$ dan $\mathrm{CO}_{2}$. Jika kandungan gas $\mathrm{CH}_{4}$ lebih dari 50\%, maka campuran gas ini mudah terbakar, kandungan gas $\mathrm{CH} 4$ dalam biogas yang berasal dari kotoran ternak sapi kurang lebih $60 \%$. Temperatur ideal proses fermentasi untuk pembentukan biogas berkisar $30^{\circ} \mathrm{C}$ (Sasse, L., 1992, Junaedi, 2002).

Pengolahan limbah atau kotoran sapi menjadi biogas merupakan salah satu solusi untuk peternakan bersih yang ramah lingkungan dan cara yang sangat menguntungkan, karena mampu memanfaatkan limbah dan bahan alami menjadi produk yang bernilai guna tanpa merusaknya sehingga siklus ekologi tetap terjaga. Manfaat lain mengolah kotoran sapi menjadi energi alternatif berupa biogas adalah dihasilkannya pupuk organik untuk tanaman, sehingga keuntungan yang dapat diperoleh adalah:

1. Meningkatnya pendapatan dengan pengurangan biaya kebutuhan pupuk dan pestisida.

2. Menghemat energi, pengurangan biaya energi untuk memasak dan pengurangan konsumsi energi tak terbarukan yaitu BBM untuk konsumsi rumah tangga.

3. Mampu melakukan pertanian yang berkelanjutan, penggunaan pupuk dan pestisida organik mampu menjaga kemampuan tanah dan keseimbangan ekosistem untuk menjamin kegiatan pertanian berkelanjutan (Sartono, 2007).

Kegiatan Pemitra di desa Ngunut kecamatan Jumantono kabupaten Karnganyar ini, diharapkan hasil pelaksanaan kegiatannya akan diperoleh tujuan dan manfaat seperti berikut :

1. Di bidang pertanian; pemanfaatan kotoran ternak (sapi dan ayam) untuk pembuatan pupuk organik, sebagai pengganti atau pendamping dalam penggunaan pupuk anorganik yang seringkali langka atau mahal di saat musim tanam, pemanfaatan lahan-lahan pertanian untuk budidaya singkong varietas unggul untuk meningkatkan tingkat pendapatan petani, dan untuk mendukung ketersediaan bahan pakan ternak.

2. Di bidang peternakan; dengan memanfaatkan kotoran ternak sapi untuk pembuatan biogas. Biogas diharapkan menjadi sumber energi alternatif pedesaan yang ramah lingkungan, menuju kemandirian energi dan pangan. Penerapan peternakan bersih diharapkan juga dapat meningkatkan nilai ekonomi yang lebih tinggi, disamping untuk menghindari terjadinya konflik sosial karena permasalahan bau dan kotoran ternak yang mengganggu lingkungan 


\section{METODE PELAKSANAAN}

Dalam melaksanakan kegiatan pengabdian Pemitra di desa Ngunut kecamatan Jumantono kabupaten Karanganyar ini, tim pelaksana telah membagi pelaksanaan kegiatan dalam pembimbingan dan pendampingan terhadap masyarakat di desa Ngunut kecamatan Jumantono Kab. Karanganyar menjadi beberapa tahapan, yaitu :

Tahap I. Pemetaan dan pendataan kondisi obyektif serta permasalahan di desa Ngunut, khususnya dalam pengelolaan peternakan ayam dan sapi, dan pemanfaatannya dalam bidang pertanian.

Tahap II. Pelatihan dan pendampingan pembuatan pupuk organik, dengan memanfaatkan hasil dari instalasi teknologi biogas yang telah dibuat pada kegiatan pengabdian dengan CSR Telkom sebelumnya.

Tahap III. Pelatihan budidaya dan pemberian bibit singkong Indonesia yang dikembangkan oleh KBD Suharno dari kec. Ampel kab. Boyolali.

Tahap IV. Evaluasi dan monitoring pengelolaan kotoran ternak untuk pembuatan pupuk organik.

Tahap V. Pengembangan pemanfaatan lahan kurang produktif dengan tanaman yang bernilai ekonomis, seperti singkong, sengon, pepaya. Tahap VI. Tahap evaluasi tentang pengembangan pertanian dan pemanfaatan lahan untuk meningkatkan produktifitas lahan.

\section{HASIL DAN PEMBAHASAN}

Pelaksanaan program Pemitra bagi pengembangan peternakan bersih di desa Ngunut kecamatan Jumantono kabupaten Karanganyar dengan tujuan utama untuk memberikan kontribusi dan alternative pemecahan masalah limbah peternakan ayam dan sapi yang banyak dilakukan oleh masyarakat desa Ngunut, serta pemanfaatan pupuk organik untuk pengembangan budidaya tanaman yang mendukung ketahanan pangan dan pemanfaatan lahan kurang produktif. Hasil pelaksanaan kegiatan pemitra di desa Ngunut telah dilakukan introduksi teknologi biogas dan pemanfaatannya sebagai sumber energy rumah tangga untuk keperluan memasak dan lampu petromak, teknologi pembuatan pupuk organik baik padatan maupu cair, serta teknologi budidaya singkong untuk pemanfaatan lahan yang kurang produktif.

Pada kegiatan pemitra desa Ngunut ini telah diintoduksikan dan dipasang teknologi biogas dengan kapasitas $9 \mathrm{~m}^{3}$ dan $15 \mathrm{~m}^{3}$ pada peternak sebagai pengenalan teknologi pengolahan kotoran sapi untuk mendukung program peternakan bersih. Dengan memanfaatkan teknologi biogas bagi peternak ini, telah diperoleh hasil yakni pengelolaan peternakan sapi yang bersih, tanpa bau, tanpa kotoran yang menumpuk, sumber lalat, juga diperoleh sumber energy biogas untuk kebutuhan memasak dan penerangan petromak.

Hasil samping yang juga diperoleh dari teknologi biogas ini berupa pupuk organik. Pemanfaatan pupuk organik untuk pengelolaan lahan pekarangan dan pertanian juga telah diintroduksikan kepada masyarakat di desa Ngunut. Tim pelaksana telah melakukan pelatihan dan pendampingan cara pembuatan pupuk organik padat dan cair, yang memanfaatkan bahan/limbah organik yang ada di sekitar masyarakat. Praktek dan pembuatan pupuk organik di desa Ngunut telah dilakukan oleh alumni fakultas Farmasi UMS beserta tim pelaksana (foto kegiatan terlampir).

Pengenalan budidaya tanaman yang bernilai ekonomis dan mudah untuk dilakukan juga telah dilaksanakan pada kegiatan pemitra ini. Budidaya singkong 
Indonesia, yang memiliki keunggulan dapat memproduksi hasil panen $40-70 \mathrm{Kg}$ perpohon telah diperkenalkan juga. Tim pelaksana pemitra telah mengundang Bapak Suharno dari kecamatan Ampel Boyolali, praktisi dan pembudidaya bibit singkong Indonesia, yang merupakan okulasi singkong lokal dengan singkong karet super. Penjelasan tentang budidaya singkong, cara budidaya singkong Indonesia dan sekaligus praktek penanaman singkong di lahan pekarangan kantor Desa Ngunut telah dilakukan pada saat pelatihan dan pendampingan. Para peserta juga diperkenalkan atau diberi bibit singkong Indonesia untuk ditanam di pekarangan rumah masing-masing.

Dengan pengenalan cara pembuatan pupuk organik yang mudah dilakukan, pelatihan dan praktek penanaman singkong Indonesia masyarakat di desa Ngunut telah tumbuh semangat \& kebersamaan untuk menanam tanaman yang dapat membantu memenuhi kebutuhan pangan keluarga di lahan pekarangan rumah. Pemanfaatan lahan pekarangan rumah ini sangat potensial, karena tanah pekarangan warga di desa Ngunut masih cukup luas, rata-rata tiap keluarga memiliki lahan $\pm 1000 \mathrm{M}^{2}$. Apabila pemanfaatan lahan pekarangan ini digunakan untuk menanam tanaman pangan yang produktif, seperti singkong Indonesia yang memiliki kemampuan produksi $40-70 \mathrm{Kg} /$ pohon tentu akan memberikan kontribusi terhadap masalah ketahanan pangan di desa Ngunut. Apalagi jika masyarakat memiliki ketrampilan untuk mengolah dan mengembangkan aneka produk olahan dari hasil produksi pertanian tentu akan meningkatkan pendapatan dan kesejahteraan masyarakat.

Tumbuhnya semangat untuk memanfaatkan lahan pekarangan ini juga ditunjukkan oleh kemauan masyarakat untuk mengajukan permohonan bibit sengon kepada Dinas Pertanian Tanaman Pangan, Perkebunan dan Kehutanan kabupaten Karanganyar. Dinas telah merespon dengan telah memberikan sumbangan bibit sengon kepada petani di desa Ngunut, dan telah ditanam pada lahan-lahan yang telah disarankan oleh tim pelaksana.

Berikut tabel yang menjelaskan kondisi masyarakat desa Ngunut sebelum dan sesudah pelaksanaan pemitra di desa Ngunut, Jumantono, Karanganyar.

Tabel 1.

Kondisi Sebelum dan Sesudah Pelaksanaan Kegiatan Pemitra di Desa Ngunut, Jumantono, Karanganyar

\begin{tabular}{|c|c|c|}
\hline Uraian & $\begin{array}{l}\text { Kondisi sebelum } \\
\text { kegiatan pemitra }\end{array}$ & $\begin{array}{c}\text { Kondisi sesudah pelaksanaan } \\
\text { Pemitra }\end{array}$ \\
\hline Pengelolaan peternakan & $\begin{array}{l}\text { Limbah kotoran dibiarkan } \\
\text { menumpuk, belum ada } \\
\text { pengelolaan yang baik }\end{array}$ & $\begin{array}{l}\text { Limbah telah dikelola dengan } \\
\text { pemanfatan instalasi biogas }\end{array}$ \\
\hline Teknologi fermentasi & $\begin{array}{lr}\text { Masyarakat } & \text { belum } \\
\text { mengetahui } & \text { dan } \\
\text { memanfaatkan } & \text { bahan } \\
\text { fermentator } & \text { untuk } \\
\text { pengelolaan peternakan }\end{array}$ & $\begin{array}{l}\text { Penggunaan } \\
\text { (probiotik) untuk mendukung } \\
\text { pengelolaan peternakan bersih } \\
\text { telah dipraktekan oleh sebagian } \\
\text { peternak }\end{array}$ \\
\hline
\end{tabular}




\begin{tabular}{|c|c|c|}
\hline Uraian & $\begin{array}{c}\text { Kondisi sebelum kegiatan } \\
\text { pemitra }\end{array}$ & $\begin{array}{c}\text { Kondisi sesudah pelaksanaan } \\
\text { Pemitra }\end{array}$ \\
\hline Pembuatan pupuk organik & $\begin{array}{lr}\text { Masyarakat } & \text { belum } \\
\text { mengetahui dan memiliki } \\
\text { ketrampilan } \\
\text { membuat pupuk organik }\end{array}$ & $\begin{array}{l}\text { Masyarakat telah mempraktekan } \\
\text { cara pembuatan pupuk organik } \\
\text { untuk mendukung pengelolaan } \\
\text { pertanian }\end{array}$ \\
\hline $\begin{array}{l}\text { Pemanfaatan } \\
\text { pekarangan }\end{array}$ & $\begin{array}{lr}\text { Masyarakat } & \text { masih } \\
\text { memanfaatkan } & \text { lahan } \\
\text { pekarangan } & \text { secara } \\
\text { konvensional } & \text { belum } \\
\text { direncanakan dengan baik }\end{array}$ & $\begin{array}{l}\text { Masyarakat telah diberi } \\
\text { pengetahuan dan ketrampilan untuk } \\
\text { memanfaatkan lahan dengan } \\
\text { budidaya tanaman singkong dan } \\
\text { sengon. }\end{array}$ \\
\hline Potensi konflik sosial & $\begin{array}{l}\text { Pengelolaan peternakan } \\
\text { yang belum memperhatikan } \\
\text { kebersihan dan } \\
\text { kenyamanan lingkungan, } \\
\text { menimbulkan potensi dan } \\
\text { problem konflik sosial di } \\
\text { masyarakat }\end{array}$ & $\begin{array}{l}\text { Pendampingan untuk mengelola } \\
\text { peternakan secara bersih, dengan } \\
\text { pemanfaatan probiotik/fermentator } \\
\text { dan pengolahan limbah menjadi } \\
\text { biogas, dapat menurunkan potensi } \\
\text { dan problem konflik sosial di } \\
\text { masyarakat. }\end{array}$ \\
\hline
\end{tabular}

Pendampingan untuk mengelola peternakan secara bersih, dengan pemanfaatan probiotik/ fermentator dan pengolahan limbah menjadi biogas, dapat menurunkan potensi dan problem konflik sosial di masyarakat.

Pelaksanaan pemitra di desa Ngunut ini tentunya menemui kendala dan hambatan, yakni :

1. Belum adanya kelompok tani yang memiliki kesatuan organisasi dalam merancang, menata, melaksanakan dan mengevaluasi program kerja. Sehingga kebersamaan dan keberlanjutan dalam melaksanakan kegiatan pengabdian masyarakat belum dapat dilakukan dengan baik.

2. Sebagian besar peserta yang aktif dalam kegiatan pemitra adalah perangkat desa dan keluarga, sehingga tidak banyak memberikan keluasan manfaat kepada masyarakat umum.

3. Desa Ngunut sudah seringkali menjadi desa mitra oleh dinas/institusi lain dan juga sering mendapat bantuan dalam kegiatan pengentasan kemiskinan dan pemberdayaan masyarakat, sehingga ada kesan kejenuhan dalam mengikuti pelaksanaan tahapan pengabdian.

\section{SIMPULAN DAN SARAN}

\section{Simpulan}

Dari kegiatan Pemitra di desa Ngunut kecamatan Jumantono Karanganyar yaitu pengembangan peternakan bersih dan pertanian organik telah diperoleh hasil sebagai berikut :

1. Pemanfaatan instalasi biogas dari kotoran sapi, telah membantu peternak untuk memperbaiki kebersihan dan kualitas lingkungan dalam peternakan sapi.

2. Hasil dari pengelolaan biogas dapat dimanfaatkan sebagai pupuk organik, yang dapat digunakan untuk melengkapi kebutuhan pupuk dalam pertanian dan pemanfaatan lahan, disamping sumber energy rumah tangga yakni kompor dan lampu petromak.

3. Dukungan, komitmen dan konsisten pejabat-pejabat dan ketua kelompok di desa Ngunut kecamatan Jumantono sangat berpengaruh terhadap keberhasilan 
dan keberlanjutan program peternaan bersih dan pertanian organik.

4. Pemanfaatan dan pengembangan pertanian dengan memanfaatkan pupuk organik limbah peternakan, dapat mengoptimalkan pemanfaatan lahan yang kurang produktif, dengan penanaman singkong, jagung, sengon dan pepaya.

\section{Saran}

Berdasarkan pembahasan dan kesimpulan di atas, kami merumuskan beberapa saran, antara lain :

1. Dukungan dan konsistensi pejabat dan ketua kelompok tani di desa Ngunut perlu ditingkatkan dan dijaga keistiqomahannya dalam pengelolaan peternakan yang bersih dan pertanian organik berbasis bahan-bahan lokal untuk pemanfaatan lahan yang masih kurang produktif.

2. Petani masih perlu didampingi dan ditingkatkan ketrampilannya untuk memanfaatkan lahan-lahan yang belum produktif, dengan budidaya tanaman yang bernilai ekonomis.

\section{PERSANTUNAN} kepada :

Ucapan terimakasih disampaikan

1. Lembaga Penelitian dan Pengabdian kepada Masyarakat (LPPM) Universitas Muhammadiyah Surakarta yang telah memberikan dukungan moril dan finansiil dalam pelaksanaan Pemitra di desa Ngunut kecamatan Jumantono ini.

2. Bapak Kepala Desa, Carik dan aparat Desa Ngunut, kecamatan Jumantono, Kab. Karanganyar

\section{DAFTAR PUSTAKA}

Afmar, Mulyadi. 1999. Faktor Kunci dan Efektif Penerapan Cleaner Production di Industr ITB. Bandung

Anonim.2010. Produksi Bersih. http.//www.produksi bersi.com/terbaru/artikeldiakses tanggal 1 Maret 2010

Hastuti, D., 2009, Aplikasi Teknologi Biogas guna Menunjang Kesejahteraan Petani Ternak, MEDIAGRO, Vol. 5, No. 1, 20-26.

Junaedi, M. 2002. Pemanfaatan Energi Biogas di Perusahaan Susu Umbul Katon Surakarta, Laporan Program Vucer 2002, Dikti-UMS, Surakarta.

Putro, S., 2007, Penerapan Instalasi Sederhana Pengolahan Kotoran Sapi Menjadi Energi Biogas di Desa Sugihan Kecamatan Bendosari Kabupaten Sukoharjo, WARTA, Vol .10, No. 2, $178-188$.

Sasse, L. 1992., Pengembangan Energi Alternatif Biogas dan Pertanian Terpadu di Boyolali Jawa Tengah, Borda-LPTP, Surakarta. 
